\title{
Do Government Transfers Reduce Conflict?
}

How can we mitigate civil unrest before it results in the breakdown of social order? Not all forms of civil unrest escalate into violence, but why do some deteriorate and others do not? Social conflicts have been solved through fiscal policy and the provision of public goods and services over the centuries. Data from India, too, show government expenditure on social services has had a significant effect on reducing riots across the country. These findings have important lessons for other countries where social order breaks down frequently, but large-scale conflict may be avoidable.

\section{Government transfers as a conflict-reduction tool}

\section{Causes of civil unrest}

Many countries across the globe have recently experienced instances of civil unrest, ranging from food riots in Asia, Africa and Latin America, to the Arab Spring, and the Occupy movement. Social discontent at rising inequalities and exclusion has driven these forms of civil unrest. But while civil unrest may result in improvements in social justice, the private and social costs of civil unrest can be high, particularly if it is violent and lasts over a long period of time.

Social conflict over the distribution of resources and power exists in all societies, and civil protests and social movements do not necessarily need to escalate into violence and destruction. The idea of using social policies to keep stability and prevent or reverse the escalation of violence is seen in Chancellor Otto von Bismarck's early social insurance programmes in Germany in 1880, which spread to the rest of Europe and formed the basis of the European welfare state. Such programmes were a response to demands from workers' movements fomented by the Industrial Revolution, and were seen as a way to keep class struggle under control.

Impact of Indian government expenditure on civil unrest

There is limited empirical evidence on whether government expenditure may prevent or reduce civil unrest, or about the type of policies that may be used to mitigate civil unrest or prevent its escalation into widespread violence. However, analyses of a unique longitudinal data set compiled for the 16 largest Indian states for the period 1960-2011 contain information on government expenditure on social services, levels of rioting, measures of inequality and poverty, and other relevant social, economic and political variables.

India is a good example of a society characterised by a high propensity for civil unrest, and where demand for government provision of public goods and services is high. Civil unrest is common and persistent in India (see Figure 1): almost 40,000 people have been killed or injured in riots in India since independence in 1947. But despite being extremely violent at times, civil unrest has not resulted into full-scale civil war. One reason may be related to how India's democratic system responds to demands from various social groups.

Figure 1 Incidence of riots in India, 1960-2011

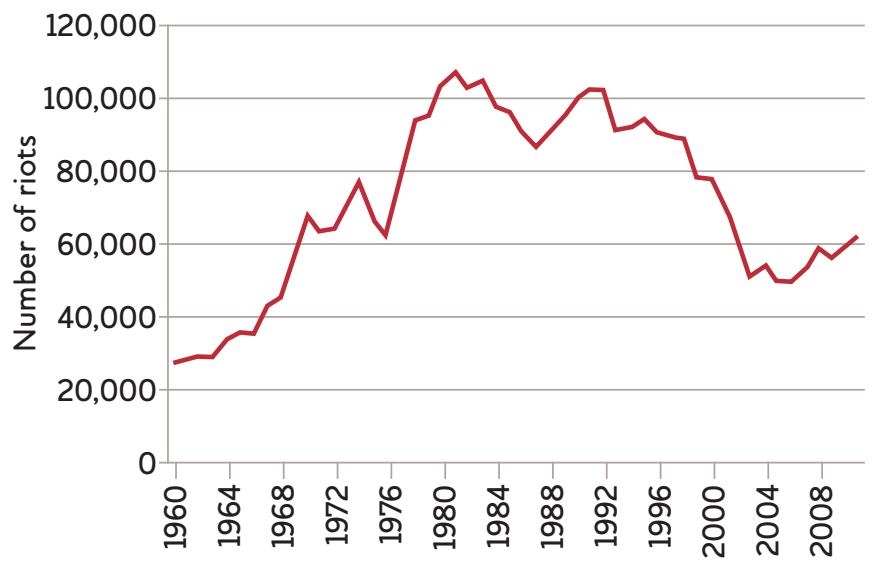

Source: Based on data from Government of India, Crime in India (New Delhi: National Crime Records Bureau, Ministry of Home Affairs, various years). "Social conflict
over the
distribution of
resources and
power exists in
all societies, and
civil protests
and social
movements do
not necessarily
need to escalate
into violence
and destruction." 
Whether intentional or not, and despite the small amounts spent, government expenditure on social services has had a significant impact on preventing and reducing civil unrest in India. This may be because of two competing mechanisms. On the one hand, government transfers can shape the preferences of citizens in ways that prevent them from resorting to violence to resolve social conflicts over distribution. On the other hand, government transfers may increase the opportunity costs of violence - people do not resort to violence because they have more to lose.

\section{Does government expenditure reduce civil unrest?}

Data analysis revealed that past levels of government expenditure on social services are associated with statistically significant reductions in rioting in India. There is at least a one-year time lag in the effect, as the effect of current expenditure has no statistically significant effect on rioting, which the delay between government expenditure and its impact on levels of social discontent is likely to cause. There is no evidence to show that the use of repressive mechanisms, such as the use of police force, are effective tools in the reduction of unrest. The results were consistent across the different models of analysis.

Additional variables affect levels of civil unrest in India; the most significant are past levels of civil unrest and state income. If a state has had a recent episode of civil unrest, it is more likely to experience another one. Levels of state income have a positive and statistically significant impact on rioting in India. Richer states may therefore expect to experience larger amounts of civil unrest, which may be because people have more to gain from rioting in these states, and levels of inequality may be higher.

Further analysis shows that the reduction in rioting in India that government transfers cause is most likely to be a result of their effects on poverty. Effects on inequality are mixed and not conclusive. The effect of government transfers may be because of their preventive nature: transfers contribute to the socioeconomic protection of the most vulnerable groups of the population, addressing important sources of social discontent.

\section{Policy implications}

- The State may have an important role in managing political and social order that goes well beyond purely being a mechanism to impose the rule of law or to establish a monopoly on violence, and as a source of grievance. Fiscal policy in particular could play a part in mitigating or preventing civil unrest.

- The findings from India contain important lessons for other countries where social cohesion tends to break down frequently, but large-scale wars may be avoidable. The results suggest that implementing adequate programmes of government transfers can have an important role to play in establishing and maintaining stable sociopolitical environments.

- Further empirical analyses of the relationship between government expenditure and social unrest should remain on the agenda of future research on political violence and social justice.

\section{Further reading}

Azam, J-P. (2001) 'The

Redistributive State and

Conflicts in Africa', Journal of Peace Research 38: 429-44

Besley, T. and Persson, T. (2010)

'State Capacity, Conflict and

Development', Econometrica 78: 1-34

Boix, C. (2003) Democracy and

Redistribution, Cambridge:

Cambridge University Press

Justino, P. (2015) Civil Unrest and Government Transfers in India, IDS Evidence Report 108, Brighton: IDS

\section{Credits}

This IDS Policy Briefing was

written by IDS Research Fellow

Professor Patricia Justino who

leads the IDS Conflict, Violence and Development Cluster, with

the support of Becky Mitchell who is the research officer for the cluster. It was edited by

Carol Smithyes. It is based on

the work conducted as part of

the IDS Addressing and

Mitigating Violence programme,

supported with UK aid from the

UK Department for

International Development.

The opinions expressed are

those of the author and do not necessarily reflect the views of

IDS or the UK government's

official policies.

Readers are encouraged to

quote and reproduce material

from the IDS Policy Briefing

series. In return, IDS requests

due acknowledgement and

quotes referenced as above..

AG Level 2 Output ID: 43

(C) Institute of Development Studies, 2015 ISSN 1479-974X 